\title{
THE CONTROL OF CODLING MOTH (CYDIA POMONELLA L.) POPULATION USING MATING DISRUPTION METHOD
}

\author{
Zofia PŁUCIENNIK \\ Research Institute of Horticulture, \\ Konstytucji 3 Maja 1/3, 96-100 Skierniewice, Poland \\ Received: June 11, 2013; Accepted: July 1, 2013
}

\begin{abstract}
The series of experiments on codling moth (Cydia pomonella L.) control using mating disruption method were conducted in three experimental orchards during 2006-2010 growing seasons. The efficacy of two commercial pheromone preparations: Ecodian CP and Isomate CTT, in comparison to pesticides Calypso 480 SC and Appeal 04 PA, was evaluated on the base of percentage of damaged fruits, number of caterpillars collected during their migration for overwintering in bands of corrugated cardboard placed on tree trunk and number of moths caught in pheromone traps. Two thousands dispensers of Ecodian $\mathrm{CP}$ were used twice a season (at 6-week interval) on the area of 1 ha of the orchard. Five hundred of Isomate CTT dispensers were applied once a season on 1 ha of the orchard. In all the experiments, application of mating disruption method significantly reduced the level of apple damage; the control efficacy (calculated according to Abbott's formula) ranged from 54.2\% to 95.8\%. The efficacy of chemical control ranged from $58.5 \%$ to $93.0 \%$. The lower efficacy of mating disruption method was noticed in orchards with high codling moth population. The treatments also affected the number of caterpillars caught in bands of corrugated cardboard placed on tree trunk. In experiments where the codling moth was not controlled, the number of caterpillars per a band varied from 0.2 to 11.9 whereas in these where the pest was controlled chemically or by mating disruption method, their number varied from 1.4 to 2.8 specimens.
\end{abstract}

Key words: codling moth, control, mating disruption, apple

\section{INTRODUCTION}

Codling moth is a major pest of apple trees in many regions. The climatic conditions in recent years favour the large number not only of codling moth (Cydia pomonella L.) but also of other pests such as leaf rollers (Torticidae) in apple orchards. The raise of economic importance of this group of pests was observed in Poland since 2000 (Płuciennik and Olszak 2006, 2010). In order to obtain fruits without any damage, there is a need to apply six or more chemical treatments in commercial orchards in a season. Some insecticides are used even more frequently, creating high risk of selecting resistant pest population. It has been confirmed by data presented in the literature on the resistance of the European codling moth population to or- ganophosphorus compounds, synthetic pyrethroids and insect growth regulators (Charmillot and Pasquier 2002, Ioriatti et al. 2003; Reyes et al. 2007). It is therefore necessary to seek for alternative methods limiting the codling moth population, among others application of female sex pheromone to decrease population density by mating disruption technique. This method is based on deploying a large number of dispensers with synthetic female pheromone in the orchard. Gradually released pheromone affects males' sexual behaviour by making difficult precise location of the females for mating. Eggs laid by females are unfertile and the next generation is less numerous (Welter et al. 2005; Verhaeghe 2005; Helsen and Polfliet 2004). In Poland, the effectiveness of mating disruption method using Ecodian CP was evaluated in 2005- 
2007 by Woźniak et al. (2008). The aim of experiments presented, conducted during 2006-2010, was to evaluate the effectiveness of codling moth control using mating disruption method under climatic conditions of Poland and to compare it to the efficacy of chemical treatments. Three orchards varying in pressure of codling moth were selected for comparison.

\section{MATERIAL AND METHODS}

The research was carried out in the experimental orchards of the Institute of Pomology and Floriculture (presently Research Institute of Horticulture) in Skierniewice, and in Dabrowice near Skierniewice (Central Poland) as well as in the commercial orchard in Miłobądz (Northern Poland). In Dąbrowice, the experiment has been conducted in two sectors: one with 'Jonagold' trees planted in 1995, and second with 'Ligol' trees planted in 1996. The orchard in Skierniewice consisted of trees planted in 1971 (cv. 'Wealthy') and in Miłobądz of trees planted in 1987 (cv. 'Idared'). Selected parts of the orchard area of 1-2 hectares were divided into three blocks. They were used as plots of the following experimental treatments:

1. Codling moth control by mating disruption method using pheromone products: Ecodian $\mathrm{CP}$ (active ingredient: 97\% (E,E)-8,10-dodecadien1-ol,) produced by ISAGRO Italy, was applied in seasons 2006-2008 and Isomate CTT (active ingredients: $53 \%$ (E,E)-8,10-dodecadien-1-ol,+ $30 \%$ dodecanol $+6 \%$ tetradecanol), produced byShin-Etsu Chemical Co., Ltd., was applied in years 2009-2010;

2. Chemical codling moth control with insecticide Calypso 480 SC (thiacloprid) applied 2 or 3 times a season during the mass flight of codling moth, or Appeal 04 PA (active ingredients: 0.1\% codlemone $+4 \%$ cyfluthrin) applied two times per season ("Attract and Kill" mode of action);

3. Control plots, where no pest control was applied.

There were three experiments using Ecodian $\mathrm{CP}$ and five using Isomate CTT. Ecodian $\mathrm{CP}$ was applied twice a season, first, when the first codling moth specimens were detected in the pheromone traps, and second 6 weeks later. Each time 2000 dispensers were distributed on the area of 1 ha. Isomate CTT was applied once a season at a time when first codling moths appeared, in the number of 500 dispensers on 1 ha plot. In each plot pheromone traps were placed on tree canopy for monitoring the moth activity as well as bands of corrugated cardboard on tree trunk to trap the caterpillars coming down to the underneath of tree for overwintering (10 bands/plot).

To evaluate the efficacy of methods of codling moth control the following observations were made: (a) the number of fruits damaged by codling moth (1-2 assessments in the season); (b) the number of caterpillars collected in bands of corrugated cardboard and (c) the number of males caught in the pheromone traps, which was monitored throughout the whole codling moth flight season (3-3.5 months).

The final assessment of codling moth control efficacy in experiments with Ecodian $\mathrm{CP}$ was based on percentage of apples damaged by caterpillars at fruit harvest. A sample consisted of 2100 fruits collected from each of the experimental plots (300 fruits from each plot x 7 replicates). For experiments using Isomate CTT the assessments of fruit damaged by the $1^{\text {st }}$ and the $2^{\text {nd }}$ caterpillar generation were made on the basis of 25 fruits collected in the second half of July from randomly chosen 20 apple trees (500 fruits from each experimental plot). The results were evaluated statistically using analysis of variance, which was carried out on data transformed according to Bliss' function. The significance of differences between means of particular experimental treatments was estimated using Newman-Keuls test at a 5\% significance level. Effectiveness of the moth control was calculated according to Abbott's formula: (AB)/A (in \%), where A and B are numbers of damaged fruits from treated and untreated plots, respectively.

\section{RESULTS AND DISCUSSION}

In each experiment, the application of mating disruption method to codling moth control resulted in a significant reduction in the number of apple fruits damaged by caterpillars and the efficacy of 
pest control ranged from $54.2 \%$ to $95.8 \%$ (Tab. 1 and 2). On chemically controlled plots, the efficacy ranged from $58.5 \%$ to $93.0 \%$.

In the experiments I, II and III, where Ecodian CP was used for codling moth control by mating disruption method, the effectiveness of treatments ranged from $62.1 \%$ to $81.2 \%$ (Table 1 ). High efficacy has been obtained in experiments I and III (Table 1), where the population of the pest in the orchards was low, the number of pestdamaged fruits on untreated plots ranged from $3.1 \%$ and $4.1 \%$. In that case, the number of pest-damaged fruits was below the economic damage threshold $(<1 \%)$. The results obtained with Ecodian CP treatments were significantly better than in plots, where Appeal 04 PA (Experiment I) or Calypso 480 SC (Experiment III) were used. Unsatisfactory results effectiveness $62.1 \%$ - were obtained in Experiment II where the population of the pest in the orchard was high - on untreated plots, the level of pestdamaged fruits reached $9.8 \%$.

In the experiments where Isomate CTT was used for codling moth control by mating disruption method (I-V, Table 2), the effectiveness of treatments ranged from $54.2 \%$ to $95.8 \%$. Similarly as in the experiments with Ecodian $\mathrm{CP}$, low efficacy was obtained in the orchards where the population of the pests was high (Experiment I, IV and V, Table 2). On untreated plots, the number of pestdamaged fruits ranged from $5.8 \%$ to $8.4 \%$. These experiments did not give satisfactory results; the number of pest-damaged fruits was above the economic damage threshold $(>1 \%)$. No positive effect of codling moth control at sites with higher pest population was also noted by other researchers (Mansour and Mohamad 2001; Woźniak et al. 2008). Low efficacy of pest control using mating disruption method in Experiment V could also be affected by the specific conditions in the orchard consisted of old, tall trees with extensive canopies. In orchards where the presence of pests was lower (Experiment II, III, Table 2), the number of pestdamaged fruits on untreated plots ranged from $1.8 \%$ to $4.8 \%$ and the effectiveness of codling moth control with Isomate CTT produced good results (number of damaged fruits was below 1\%), comparable to the plots with chemical insecticide treatment. The results of codling moth control with both, Ecodian CP and Isomate CTT, were similar and proved to produce satisfactory results in orchards with low pest population.

In the control plots (no protection) the pheromone traps were also present in order to monitor the number of caught males, which varied from 102 to 311 per a trap and season (Table $1 \&$ $2)$. However, in parts of the orchards where codling moth population was controlled by mating disruption method with Ecodian $\mathrm{CP}$ or Isomate CTT, none or just single males were found in pheromone traps. The only exception was the Experiment I (2006, Table 1), where after 5 weeks from the date of Ecodian CP application, the vast number of codling moth was noted. This was the signal for the second application of the Ecodian $\mathrm{CP}$, which resulted in the reduction of caught males and the final efficacy of the pest control in this experiment reached $81.2 \%$. Similar results were also obtained in Slovenia, where there was a need for re-application of Ecodian CM (after 50 days) in experiments on the control of peach moth Laspeyresia molesta (Rot 2008). However, according to Angeli et al. (2007) Ecodian CP VP sex pheromone dispensers were active during the entire vegetation period. Low efficacy of codling moth control was obtained in the Experiment I (2009, Table 2), where Isomate CTT was applied only once and during the season over 25 males were found in the pheromone traps, and the efficacy of treatment was $54.2 \%$. It was also found that despite the fact that no males were caught in pheromone traps, caterpillars of codling moth damaged the fruits, which may indicate that the attractiveness of natural female pheromones was higher than the attractiveness of synthetic compounds.

The number of caterpillars caught in bands of corrugated cardboard on tree trunks depended on the method applied for pest control. The average number of caterpillars collected in a band on one tree in untreated plots varied between 0.2 and 11.9 (Table 1 \& 2), whilst in the plots where pest was controlled by chemicals pesticides and mating disruption technique the maximum number of caterpillars per one tree was, on average, 1.4 and 2.8, respectively. 
Table 1. Efficacy of Ecodian CP in codling moth (Cydia pomonella L.) control (\%) on apple trees

\begin{tabular}{|c|c|c|c|c|}
\hline Treatments & $\begin{array}{l}\text { Damaged fruits } \\
\text { at harvest }(\%)\end{array}$ & Efficacy $(\%)$ & $\begin{array}{l}\text { Mean number } \\
\text { of caterpillars } \\
\text { per a band/ tree }\end{array}$ & $\begin{array}{c}\text { Number } \\
\text { of moths/ trap/season }\end{array}$ \\
\hline Experiment I - 2006 & \multicolumn{4}{|c|}{ Dąbrowice, 'Jonagold' cv. } \\
\hline Untreated & $4.1 \mathrm{c}^{* *}$ & - & 1.5 & 102 \\
\hline Ecodian CP $-2 \mathrm{x}^{*}$ & $0.8 \mathrm{a}$ & 81.2 & 0.2 & 51 \\
\hline Appeal 04 PA $-2 x$ & $1.2 \mathrm{~b}$ & 70.3 & 0.7 & 42 \\
\hline Experiment II - 2008 & \multicolumn{4}{|c|}{ Dąbrowice, 'Ligol' cv. } \\
\hline Untreated & $9.8 \mathrm{c}$ & - & 11.9 & 311 \\
\hline Ecodian $\mathrm{CP}-2 \mathrm{x}$ & $3.7 \mathrm{~b}$ & 62.1 & 2.8 & 3 \\
\hline Calypso $480 \mathrm{SC}-2 \mathrm{x}$ & $2.2 \mathrm{a}$ & 77.1 & 1.4 & lack of data \\
\hline Experiment III - 2008 & \multicolumn{4}{|c|}{ Dąbrowice, 'Jonagold' cv. } \\
\hline Untreated & $3.1 \mathrm{c}$ & - & 1.4 & 247 \\
\hline Ecodian CP $-2 x$ & $0.7 \mathrm{a}$ & 76.9 & 0.1 & 0 \\
\hline Calypso 480 SC - 2 x & $1.3 \mathrm{~b}$ & 58.5 & 0.5 & 228 \\
\hline
\end{tabular}

* number of treatments

**Means in columns marked by the same letter are not significantly different according to Newman-Keuls test $(\mathrm{p}=5 \%)$

Table 2. Efficacy of Isomate CTT in codling moth (Cydia pomonella L.) control on apple trees

\begin{tabular}{|c|c|c|c|c|c|c|}
\hline \multirow[b]{2}{*}{ Treatments } & \multicolumn{2}{|c|}{$1^{\text {st }}$ generation } & \multicolumn{2}{|c|}{$2^{\text {nd }}$ generation } & \multirow{2}{*}{$\begin{array}{c}\text { Mean number } \\
\text { of caterpillars } \\
\text { per a } \\
\text { band/tree }\end{array}$} & \multirow[b]{2}{*}{$\begin{array}{l}\text { Number of } \\
\text { moths } \\
\text { /trap/season }\end{array}$} \\
\hline & $\begin{array}{c}\text { Damaged } \\
\text { fruits at } \\
\text { harvest }(\%)\end{array}$ & $\begin{array}{c}\text { Efficacy } \\
(\%)\end{array}$ & $\begin{array}{c}\text { Damaged } \\
\text { fruits at } \\
\text { harvest }(\%)\end{array}$ & $\begin{array}{c}\text { Efficacy } \\
(\%)\end{array}$ & & \\
\hline Experiment I - 2009 & \multicolumn{6}{|c|}{ Dąbrowice, 'Ligol' cv. } \\
\hline Untreated & $4.2 \mathrm{c}^{* *}$ & - & $5.8 \mathrm{c}$ & - & 2.4 & 244 \\
\hline Isomate CTT - $1 \mathrm{x}^{*}$ & $1.4 \mathrm{~b}$ & 66.7 & $2.7 \mathrm{~b}$ & 54.2 & 1.2 & 25 \\
\hline Calypso 480 SC - 2x & $0.0 \mathrm{a}$ & 100.0 & $0.4 \mathrm{a}$ & 93.0 & 0.0 & 180 \\
\hline Experiment II - 2009 & \multicolumn{6}{|c|}{ Dąbrowice, 'Jonagold' cv. } \\
\hline Untreated & $4.2 \mathrm{c}$ & - & $4.8 \mathrm{c}$ & - & 2.4 & 184 \\
\hline Isomate CTT - 1x & $0.6 \mathrm{~b}$ & 85.7 & $0.2 \mathrm{a}$ & 95.8 & 0.5 & 0 \\
\hline Calypso 480 SC - 2x & $0.0 \mathrm{a}$ & 100.0 & $0.8 \mathrm{a}$ & 83.3 & 0.6 & 87 \\
\hline Experiment III - 2009 & \multicolumn{6}{|c|}{ Miłobądz, 'Idared' cv. } \\
\hline Untreated & lack of data & - & $1.8 \mathrm{~b}$ & - & lack of data & 193 \\
\hline Isomate CTT - $1 \mathrm{x}$ & lack of data & lack of data & $0.3 \mathrm{a}$ & 84.4 & lack of data & 1 \\
\hline Calypso 480 SC - 2x & lack of data & lack of data & $0.8 \mathrm{a}$ & 88.9 & lack of data & 59 \\
\hline Experiment IV - 2010 & \multicolumn{6}{|c|}{ Dabrowice, 'Jonagold' cv. } \\
\hline Untreated & $8.2 \mathrm{c}$ & & $8.4 \mathrm{c}$ & - & 5.2 & 231 \\
\hline Isomate CTT - $1 \mathrm{x}$ & $3.2 \mathrm{~b}$ & 61.0 & $2.9 \mathrm{~b}$ & 65.4 & 2.1 & 0 \\
\hline Calypso 480 SC-3x & $1.6 \mathrm{a}$ & 80.5 & $0.9 \mathrm{a}$ & 88.8 & 0.4 & lack of data \\
\hline Experiment V - 2010 & \multicolumn{6}{|c|}{ Skierniewice, 'Wealthy' cv. } \\
\hline Untreated & $6.2 \mathrm{c}$ & - & $6.0 \mathrm{c}$ & - & 0.2 & 228 \\
\hline Isomate CTT - $1 \mathrm{x}$ & $3.0 \mathrm{~b}$ & 51.6 & $2.7 \mathrm{~b}$ & 54.2 & 0.0 & lack of data \\
\hline Calypso 480 SC - 2x & $1.2 \mathrm{a}$ & 80.6 & $0.8 \mathrm{a}$ & 86.4 & 0.0 & lack of data \\
\hline
\end{tabular}

*** for explanations see Table 1. 
Only in the Experiment VIII, despite of the high codling moth population density, the number of caterpillars in bands was low (average of 0.2 caterpillars per a tree at untreated plot). This could be due to the old age of trees in the experimental orchard. Cracks in the bark on the trunks of old trees create good conditions for caterpillars to find places for overwintering before they reach the bands.

The presented results show that the mating disruption method can be used as an alternative for reducing the codling moth population as well as the level of fruits damage in apple orchards managed both in the integrated and organic production systems. It is in fact a method completely safe for beneficial fauna and the surrounding environment. However, when using this method of control in the commercial orchards with high pest population, in order to produce fruits without any damage, the accurate monitoring of the pest is required, and, if necessary, supplementary treatments with biological or chemical products should be applied (Benvenuto and Totis 2009; Vreysen et al. 2010). Mating disruption technique is also an alternative for codling moth control in orchards, where the pest resistance to insecticides was already noted or to prevent the selection of resistant strains due to frequent treatments with synthetic pesticides (Charmillot and Pasquier 2002; Ioriatti et al. 2002; Sauphanor et al. 2002). This method is less suitable in orchards comprising old apple trees, which grow in a conventional manner (large row spacing and large trees with high crowns in a row). In such conditions, it is impossible to obtain a uniform cloud of odour and the male disorientation is not sufficient. Another limitation of widespread use of mating disruption technique in orchards is also the high cost of products and the need for manual application of dispensers. However, replacement of manual application by production and use of the product as capsules for orchard spraying could reduce the cost of treatment (Kovanci et al. 2010; Witzgall et al. 2008).

\section{CONCLUSIONS}

1. The control of codling moth by mating disruption technique using Ecodian $\mathrm{CP}$ and Isomate CTT pheromone preparations reduced the num- ber of damaged fruits by $54.2 \%$ to $95.8 \%$ in comparison to untreated plots.

2. Low effectiveness of codling moth control using Ecodian CP or Isomate CTT was obtained in orchards with high population density of the pest.

\section{REFERENCES}

Angeli G., Anfora G., Baldessari M., Germinara G.S., Rama F., Cristofaro A. De, Ioriatti C. 2007. Mating disruption of codling moth Cydia pomonella with high densities of Ecodian sex pheromone dispensers. J. App. Ent. 131: 311-318

Benvenuto L., Totis F. 2009. A new method for the control of codling moth: sexual auto-confusion with Exosex CM. Notiziaro ERSA. 22: 10-13.

Charmillot P.J., Pasquier D. 2002. Progression de la resistance du carpocapse Cydia pomonella aux insecticides. Revue Suisse Vitic. Arboric. Hortic. 34 (2): 95-100.

Helsen H., Polfliet M. 2004. Control of codling moth. Fruitteelt Den Haag 94(21): 14-15.

Kovanci O.B., Kumral N.A., Larsen T.E. 2010. High versus ultra-low volume spraying of a microencapsulated pheromone formulation for codling moth control in two apple cultivars. J. Pest Manag. 56: 1-7.

Ioriatti C., Boselli M., Butturini A., Mattedi L., Rizzi C., Vergnani S. 2002. Integrated resistant management of codling moth Cydia pomonella $\mathrm{L}$. in Italy. VII ${ }^{\text {th }}$ European Congress of Entomology, October 7-13 2002, Thessaloniki Greece, p. 162.

Ioriatti C., Bouvier J.C., Butturini A., Cornale R., Tiso R. 2003. Codling moth: the current status of insecticide resistance in the major pipfruit growing regions in Italy. Informatore Fitopatologico 53(1): 53-59.

Mansour M., Mohamad F. 2001. Mating disruption for codling moth, Cydia pomonella (L.) (Lepidoptera: Tortricidae), control in Syrian apple orchards. Polish J. Ent. 70(2): 151-163.

Płuciennik Z., Olszak R.W. 2006. Wykorzystanie pułapek feromonowych do monitoringu owocówki jabłkóweczki i zwójkówek liściowych w sadach. Prog. Plant Protect./Post. Ochr. Rośl. 46: 399-402.

Płuciennik Z., Olszak R.W. 2010. Monitoring czterech gatunków zwójkówek liściowych w sadach z wykorzystaniem pułapek feromonowych. Prog. Plant Protect./Post. Ochr. Rośl. 50: 1725-1728.

Reyes M., Franck P., Charmillot P.J., Ioriatti C. Olivares J., Pasqualini E., Sauphanor B. 2007. Diversity of 
insecticide resistance mechanisms and spectrum in European populations of codling moth, Cydia pomonella. Pest Manag. Sci. 63: 890-902.

Rot M. 2008. Ecodian CM pheromone dispensers - a new possibility for controlling peach moth. SAD, Revija za Sadjarstwo Vinogradnistvo in Vinarstwo 19(3): 6-7.

Sauphanor B., Boivin T., Beslay D., Bouvier J.C. 2002. Integrated management of insecticide resistance in French codling moth populations. VII ${ }^{\text {th }}$ European Congress of Entomology, October 7-13 2002, Thessaloniki, Greece, p.161.

Verhaeghe A. 2005. Control of walnut codling moth: mating disruption. Infos Ctifl. 208: 42-45.

Vreysen M.J.B., Carpenter J.E., Marec F. 2010. Improvement of the sterile insect technique for cod- ling moth Cydia pomonella (Linnaeus Lepidoptera) to facilitate expansion of field application. J. App. Ent. 134: 165-181.

Welter S.C., Pickel C., Millar J., Cave F., Steenwyk R.A., Dunley J. 2005. Pheromone mating disruption offers selective management options for key pests. California Agriculture 59(1): 16-22.

Witzgall P., Stelinski L., Thonson D. 2008. Codling moth management and chemical ecology. Ann. Rev. Ent. 53: 503-522.

Woźniak K., Dąbrowski Z.T., Sowiński A. 2008. Czynniki warunkujące efektywne wykorzystanie metody dezorientacji samców owocówki jabłkóweczki (Carpocapsa pomonella L.). Prog. Plant Protect./Post. Ochr. Rośl. 48 (4): 1378-1382. 